\title{
The Effectiveness of Blended Learning With the Syncronous and Asyncronus System in Civic Education Courses
}

\author{
Cahyono Cahyono ${ }^{1, *}$, Endang Danial ${ }^{2}$, Idrus Affandi ${ }^{3}$, Iim Siti Masyitoh ${ }^{4}$
}

\author{
${ }^{1}$ Universitas Pasundan, Bandung, Indonesia \\ 2,3,4 Universitas Pendidikan Indonesia, Bandung, Indonesia \\ *Corresponding author. Email: cahyono@unpas.ac.id
}

\begin{abstract}
The $21^{\text {st }}$ century is one of the most rapid technological developments. With the term industrial revolution 4.0, it has driven various technological advances in various fields of life. The advancement of educational technology is one of the impacts of technological developments that occurred in the $21^{\text {st }}$ century during the 4.0 industrial revolution. Educational technology is prepared to face the era of society 5.0. The creation of distance learning (PJJ) or online learning is one of the impacts of technological advances in education. In order for online learning to run optimally, collaboration is needed between virtual face-to-face learning and full online learning or an assignment system. The combination of virtual face-to-face learning with online assignments is known as syncronous and asyncronous blended learning systems. This study aims to determine the effectiveness of blended learning with syncronous and asyncronous systems in civic education courses. Qualitative approaches and descriptive analysis methods are used in research to obtain accurate analysis results, with data collection techniques through surveys through questionnaires, and obtained through data reduction systems, data displays, and data reduction. The results showed that blended learning with syncronous and asyncronous systems could facilitate the level of student understanding of the course material in following lectures in civic education courses. In addition, it can also increase students' creativity and criticality in doing analytical tasks during syncronous and asyncronous learning.
\end{abstract}

Keywords: Asyncronous, Blended Learning, Civics Learning, Synchronous.

\section{INTRODUCTION}

The 21 st century has made many advances in various fields of life, one of which is information technology and telecommunications. The industrial revolution 4.0 has opened up space to welcome the era of society 5.0, where all areas of life are influenced by technology, one of which is the use of internet networks in various fields of life.

Internet technology was very influential during the 4.0 industrial revolution and this is the initial gate to enter the era of society 5.0. This is evidenced by the use of internet media in various aspects of life. This means that life today cannot be separated from the use of the internet network to facilitate human life in daily activities [1].

Technological advances have had a major impact on the world of education. Where educational technology has developed rapidly following technological developments in general, one of the technological developments in education is the learning process that can be done remotely or via a network (online).
The use of the internet in the learning process causes many learning models to be developed, one of which is blended learning. A number of research results show that the Blended Learning learning model has a positive influence on learning, starting from the teaching and learning process [2], learning motivation, and student learning outcomes [3]. In addition, this learning model is very suitable when used as a learning model in the $21 \mathrm{st}$ century era and the future [4]. Thus, the blended learning process during the covid-19 pandemic with the synchronous and asynchronous system is very effective, because there are two advantages, firstly, the learning process can still be carried out, and the learning objectives or achievements can be achieved properly. The second advantage is that it can prevent the spread of COVID-19.

We know that at this time, the COVID-19 pandemic has become a world disaster that has an impact on all aspects of life, including education. This condition requires all educational institutions to carry out learning innovations that are usually carried out in schools. The implementation of learning must be done online [5]. The use of advances in learning technology during the Covid- 
19 pandemic is a form of sensitivity of educational institutions in responding to environmental changes. The ability of an institution to respond to changes in its external environment is the main factor that determines the performance of the institution [6]. With the presence of blended learning with synchronous and asynchronous systems, it has had a positive impact on the process of education, especially in the learning and learning process.

Blended Learning refers to learning that combines or mixes face-to-face learning and internet-based learning (online) [7]. Blended Learning is a type of learning that combines classical teaching (face to face) with online teaching. Blended Learning combines aspects of web/internet-based learning, video streaming, synchronous and asynchronous audio communication with traditional 'face-to-face' learning [8].

Based on the brief description above, the purpose of this study is to find out how effective blended learning is with synchronous and asynchronous systems, seen from the content of the material, students' level of understanding, critical thinking skills and students' creativity in the learning process of Civics courses.

\section{THEORETICAL REVIEW}

The current condition of the Covid-19 pandemic in the world has a major impact on the world of education, one of which is the world of education in Indonesia. This has a negative impact on the order of life, one of which is the realm of education [9]. The learning process during the pandemic is carried out online, with the aim of reducing the level of spread of COVID-19. For this reason, the online learning process must be carried out in various ways, so that learning objectives and achievements are still achieved properly. Blended learning or a combination of assignment learning and virtual face-to-face learning is felt to be effective in the process of implementing online learning during the COVID-19 pandemic.

The implementation of blended learning during the Covid-19 pandemic was carried out by giving assignments online, and face to face with students via video conference to determine student involvement in learning. With this system, learning remains like teaching and learning in the classroom, only the place and time are different [10]. Blended learning is a combination of two very different learning models, namely the traditional face-to-face learning model with a modern technology-based learning model [11].

Blended Learning is a mixed learning pattern between classroom (face-to-face) and online (webinar, LMS) learning. However, during this pandemic, the online method used is the use of multimedia, both synchronous and asynchronous. [12] state that there are four learning spaces in blended learning, namely live synchronous, virtual synchronous, self-paced asynchronous, and collaborative asynchronous. Direct synchronization (live synchronous) is learning that is carried out directly face to face in the same time and place (real time). Classroom learning which is usually carried out in schools with faceto-face interactions between teachers and students is in direct synchronization. Virtual synchronous (virtual synchronous) is learning that is carried out directly with virtual eyes at the same time (real time) but in different places. Virtual-to-virtual learning using various video conferencing technologies is virtual synchronous. Asynchronous self (self-directed asynchronous) is learning that is done independently anytime and anywhere. For example through video, television, radio, or podcasts, etc. Asynchronous collaboration (collaborative asynchronous) is learning that is done together with other people anytime and anywhere. For example through online discussion forums, blogs, lark, etc.

\section{METHODS}

The method used in this research is a survey method with data collection techniques in the form of online interviews through google forms which are distributed to respondents. The instrument used is an open interview instrument, where respondents are given the freedom to provide answers to the questions given. The research sample was 25 people from 5 study programs at the University's FKIP taken using the random sampling technique, which was taken from 5 classes of 2019 students from 5 different study programs. Data processing uses data reduction techniques, data presentation, and drawing conclusions. Data analysis used descriptive analysis method with a qualitative approach.

\section{RESULTS AND DISCUSSION}

Lectures using the blended learning method with synchronous and asynchronous systems in Civics courses at FKIP Unpas are running well and effectively in helping to improve students' understanding and critical thinking skills. This can be seen from two indicators; First, the ease of interaction and communication patterns in the form of questions and answers or direct discussions via video conference with the Zoom Meeting and Google Meet applications. Second, the lecture process can be done easily, because you can use a cellphone or laptop that can be followed by an unlimited number of places, as long as the internet network and internet quota are sufficient.

In the learning process, both synchronously and asynchronously, the lecturer delivers the material according to the Semester Learning Plan (RPS) which has been delivered at the beginning of the lecture to students, so that students can easily attend lectures at each meeting. In addition, the delivery of material is discussed directly by the lecturer in both synchronous and asynchronous sessions using learning videos that have been prepared by the lecturer. The task given by the lecturer in the asynchronous session is a case analysis or task that is factual and contextual, so that it can improve students' 
abilities in developing creativity and analytical and critical thinking skills.

The entire series of lectures, synchronous and asynchronous, can run well if carried out by lecturers and students according to a predetermined schedule, and with internet network facilities, as well as adequate equipment, including the availability of internet quota on the devices used.

The assessment of lectures at synchronous time is carried out by observing the activeness of students in providing arguments and analysis, as well as the courage to ask questions and express opinions during virtual discussion sessions. In addition, attitude assessment is also carried out by looking at the grammar and ability of students in giving opinions, and receiving opinions from friends, then always turning on the video camera during lectures or during discussions.

While the assessment in the asynchronous session is carried out based on the tasks that have been given in a structured manner from each meeting. Discipline in collecting assignments and the ability to analyze, as well as creativity in completing coursework, are important indicators in the assessment of asynchronous lecture sessions.

\section{CONCLUSION}

The learning process for Civics courses using blended learning with synchronous and asynchronous systems is very effective, especially during the Covid-19 pandemic. This is evidenced by the learning outcomes of Civics courses that have been achieved by students even though the lectures are not conducted face-to-face in class.

Blended learning with synchronous and asynchronous systems can be carried out well if done with careful preparation, starting from the preparation of semester learning plans (RPS), learning methods and media to be used, types and techniques of assignment, internet network facilities and adequate devices. that will be used during the lecture, as well as the internet quota available on the device that will be used.

\section{REFERENCES}

[1] Ahmad Noval. 2020. Blended Learning-Based Learning Management During the Covid-19 Pandemic. Jurnal Islamic Education Manajemen. 5 (2) (2020) 201-220.

[2] Banggur, M. D. V., Situmorang, R., \& Rusmono, R. (2018). Development of Blended LearningBased Learning in Multimedia Etymology Subjects. JTP - Jurnal Teknologi Pendidikan, 20(2), 152-165

[3] Isti'anah, A. (2017). The Effect Of Blended Learning to The Stidents' Achievement in Grammar Class. Indonesian Journal of English Education, 4(1), 16-30.

[4] Hasbullah, H. (2014). Blended Learning, the Trend of Future Mathematics Learning Strategies. Jurnal Formatif, 4(1), 65-70.

[5] Syah, R. H. S. (2020). The Impact of Covid-19 on Education in Indonesia: Schools, Skills, and the Learning Process. SALAM: Jurnal Sosial Dan Budaya Syar-I, 7(5), 395-402.

[6] Kuratko, D. F., Goodale, J. C., \& Hornsby, J. S. (2001). Quality Practices for a Competitive Advantage in Smaller Firms. Journal of Small Business Management, 39(4), 293-311.

[7] Idris, H. (2018). Blended Learning Model. Jurnal Ilmiah Iqra', 5(1), 61-73.

[8] Sjukur, S. B. (2013). The Effect of Blended Learning on Learning Motivation and Student Learning Outcomes at the Vocational High School Level. Jurnal Pendidikan Vokasi, 2(3), 368- 378.

[9] Muh Fitrah, Ruslan Ruslan (2021). Exploration of the Implementation System for Learning Evaluation in Schools During the Covid-19 Pandemic in Bima. Jurnal Elementari Education. Vol. 5-No. 1

[10] Budi Haryati. 2021. Blended Learning as an Effective Method in the Pandemic Era. Radar Semarang Digital. 4 Maret 2021 10:57

[11] Syifa Silvana. 2021. Is the Blended Learning Method Effective in the Midst of the Covid-19 Pandemic. kumparan.com

[12] Chaeruman, Uwes A. dan Santi Maudiarti. (2018). Quadrant of Blended Learning: a Proposed Conceptual Model for Designing Effective Blended Learning. Jurnal Pembelajaran Inovatifl(1) (2018): 1-5. 